\title{
Interaction Between Religion and Philosophy
}

\author{
Zaprulkhan \\ Fakultas Dakwah \\ IAIN Syaikh Abdurrahman Siddik Bangka Belitung, Indonesia \\ zaprulkhan_zahra@yahoo.co.id
}

\begin{abstract}
The relationship between religion and philosophy, in the view of experts, has similarities as well as differences. Religion and philosophy in grasping the truth have several similarities and differences. In religion, true truth must be guided by revelation or belief. The use of reason is only to enrich the analysis of truth. Whereas in philosophy, truth must be approached using reason through a process of reasoning. Although the truth presented by religion may be similar to the truth achieved by philosophy, religion still cannot be equated with philosophy. This difference is due to a different perspective. This article will focus on the relationship between religion and philosophy. There are several paradigms that are presented about the relationship of religion and philosophy including paradigms of contrast, subordinative, and integralistic. This paper will take the position of integrative paradigm.
\end{abstract}

Keywords: Interaction, Religion, Philosophy

\section{A. Introduction}

In the perspective of experts, both religion and philosophy basically have in common. Both have the same goal, which is to reach the true truth. But behind these similarities, there are also a number of differences between the two. In philosophy, to get the ultimate truth, humans must look for it themselves by using the tools they have in the form of all physical and spiritual potential. Whereas in religion, to get that ultimate truth man not only seeks himself, but he must accept the things revealed by God. In other words, the religious approach uses belief or faith.

Although the truth presented by religion may be similar to the truth achieved by philosophy, religion still cannot be equated with philosophy. This difference is due to a different perspective. On the one hand, religion uses belief, on the other hand philosophy is 
based on research that uses human potential, and believes it as the only measuring tool of truth, namely human reason. ${ }^{1}$

This chapter will focus on the relationship between religion and philosophy. There are several paradigms that are presented about the relationship of religion and philosophy, here include the paradigm of contrast, subordinative, and integralistic. This paper will take the position of integrative paradigm. For this reason, at the end of the chapter, deeper exploration of the integrative paradigm from an Islamic perspective will be explored.

\section{B. Relation between Religion and Philosophy}

When discussing the relationship between religion and philosophy in reaching for truth, in general there are three paradigms.

\section{The Contrast Paradigm}

The first paradigm says that both religion and philosophy have different methods from each other in reaching for truth so it is also called the paradigm of contrast. In the case of religion, truth first rests on revelation or hadith, then is accepted in the heart through belief or faith; Then it will be strengthened by rational analysis and finally it will be accepted again by the heart as final truth or absolute truth. In this case, the philosophical explanation of its intrinsic purpose is not to seek the truth, because the truth has been guaranteed to be absolutely and final by revelation or hadith, but only to enrich the truth that has been voiced by the revelation with logical-rational arguments. ${ }^{2}$

For this reason, the specific approach to religion is also called the dogmatic approach. That is, the dogmas of fundamental religious doctrines that most determine what is called truth and other tools, such as reasoning, are only secondary components. Even without the support of reason, the truth displayed by the revelation or hadith is sufficient, complete, absolute and final. The truth that has been ordained by revelation or hadith (religion) must not be questioned, contested, criticized, let alone doubt the validity of its value by the faculty of human ratio. In a dogmatic approach, the role of religious doctrine is absolute and reason only acts as an obedient helper to whatever is revealed by revelation. In the presence of the sacred command of revelation, reason becomes frozen, and is trapped in its creative creativity.

1 Juhaya S. Praja, Aliran-aliran Filsafat dan Etika, (Bogor: Kencana, 2003), p. 16.

${ }^{2}$ See in Abid al-Jabiri, Formasi Nalar Arab, terj. Imam Khoiri (Yogyakarta: Ircisod, 2003), p. 121-216. Hanafi, Pengantar Teologi Islam (Jakarta: Pustaka Al-Husna, 2003). 
If so the religious approach in reaching for truth, then the philosophical approach is very diametrically different from the religious approach in reaching for truth. In the philosophical paradigm, truth must be explored through a framework of reason and reasoning with a number of questions, anxiety, and philosophical investigations. The final result in a philosophical tentative wandering of the truth yielded two possibilities: the insight into the truth he had reached could be accepted or rejected. If in a dogmatic approach, the results they achieve are certainly accepted and are absolute, in the philosophical spotlight, the results are not necessarily accepted, it may even be rejected and relative.

Talk about God and His existence, for example, philosophy will raise a number of critical-philosophical questions: Who is God? Is God Almighty, Perfect, Most Great with all the other attributes of perfection? Then how do you recognize God with all the perfection of attributes inherent in His Essence? Then how to prove His existence? Can His existence be known through the vast universe, sky, stars and oceans? Or through the phenomenon of human life with all the problems that surround it?

With the philosophical questions above, some philosophers finally discover who God is and the paths to His existence. Philosophers who have arrived at the realm of philosophical discoveries, framing their discoveries with a number of terms: cosmological, ontological, teleological arguments, divine or religious experiences, and moral arguments. ${ }^{3}$ Nevertheless, it turns out that not all philosophers accept all these philosophical arguments. Today Some of them are still there who reject all philosophical arguments about God.

In the tradition of conversation about the existence of God, classically, call Karl Marx, Emile Durkheim, Friedrich Nietzsche, Ludwig Feuerbach, Sigmund Freud, Jean Paul Sartre, Albert Camus, and Bertrand Russell who reject the existence of God. ${ }^{4}$ And in the contemporary era which is still alive and actively rolling out scientific discourses about its rejection of the existence of God are scientists Richard Dawkins and Christoper Haris. ${ }^{5}$

\section{Integralistic Paradigm}

3 William J. Wainwright, Philosophy of Religion (New York: Wadsworth Publishing Company, 1999).

${ }^{4}$ Louis Leahy, Aliran-Aliran Besar Ateisme (Yogyakarta: Kanisius, 1985); John Raines (eds.), Marx Tentang Agama, terj. Ilham B. Saenong (Jakarta: Teraju, 235-266; Bertrand Russell, Bertuhan Tanpa Agama (Yogyakarta: Resist Book, 2008).

${ }^{5}$ Karen Armstrong, The Case for God, (London: The Bodley Head, 2009), 289-295. Richard Dawkins, The God Delusion (London: Black Swan, 2007). 
The second paradigm actually departs from disagreement with the first paradigm above. The distinction made in the first paradigm actually oversimplifies the problem, because in religion it includes empirical, rational, and spiritual dimensions. In this holistic meaning frame, the second paradigm is also called the integrative paradigm. In the Islamic context, in general there are at least three approaches to reaching the truth, namely the empirical approach, the rational approach that is specifically within the realm of philosophy, and the spiritual approach.

First, the empirical approach. The method of tajribi or the method of observation is through observing the senses that we have. By observing the senses, we can recognize the objects that are around us from various (five) dimensions, namely shape, sound, smell, touch, and taste. But for scientific purposes, who want to know things as they really are, our daily sense observations are not enough to give or perceive physical objects as they are, because it often happens that information that is often captured by conventional sensory observation is wrong. For example, the roar of lightning that we hear may not necessarily occur when we hear it. Likewise, the starlight that we saw last night, is not a star that exists today, but can be a star that is seven million years old, that is the amount of time needed by the star's light to reach our eyes. Thus, it is clear some of the weaknesses or limitations of these sensory observations. ${ }^{6}$

For this reason, scientific experts formulated a number of steps to help refine sensory observation: (1) measurement. Measurement is an effective way to determine a more accurate measure of distance than can be perceived by the sense of sight. From measurements of distance (area and circumference) of an object (parcels of land), a field of science emerged called surveying. By directly measuring the distance or the size of the object we see, we can overcome the error of visual observation.

In addition to measurement, the second step (2) the method of sensory observation (observation), this can be done using assistive devices, such as a sophisticated observatory or telescope at this time that has enabled more accurate sense observation with regard to physical objects at a distance - such as objects in space (stars, planets, galaxies, supernovas, etc.) —or magnifying glasses, even microscopes for observing small objects,

\footnotetext{
${ }^{6}$ Mulyadhi Kartanegara, Integrasi Ilmu, (Bandung: Arasy, 2005), p. 134.
} 
such as germs, fungi, bacteria, cells, etc. or electroscopes for observation with respect to atoms and their parts - hadrons and quarks.

The third step (3) is to conduct experiments (tajribat) about things that are not yet clear in our sensory observations, such as the question, whether we can see a physical object, because our eyes emit light, or because there is light reflected to the our eyes. ${ }^{7}$

At this point, the normative question is whether the empirical method is recommended in Islam? More specifically, is the Qur'an as the sacred word of God and the fundamental reference book of Muslims directing exploration of the universe through experimental methods? The answer turned out to be very surprising and amazing.

According to research by the University of Cairo Professor, Sheikh JauhariThanthawi in his interpretation book, Al-Jawahir, in the Qur'an there are actually more than 750 verses of kauniyah, verses that talk about the universe with its various trinkets. But in a more intensive study conducted by AgusPurwanto, D.Sc (Doctor of Science), Indonesian Muslim scientist in the field of theoretical physicists, from 6,236 verses of the Qur'an, it was found 1,108 verses about kauniyah. ${ }^{8}$

With thousands of verses of the Kauniyah, the Qur'an speaks about the universe, from the great phenomena of the heavens, the earth, the moon and other planets to the smallest facts of atomic and subatomic particles. The Qur'an not only touches on the amazing origin of the creation of the universe, the phenomenon of the sky without pillars, the theory of relativity of space and time, unique facts in humans and animals, but also discusses secrets in the fields of archeology and photosynthesis, and various scientific cues that have not yet been unraveled by the world of science to this day.

It is precisely at this point that it is no exaggeration if a great Muslim scholar from Egypt, Hassan Hanafi stated beautifully: 'Nature is an open book, like the Quran is an open nature. ${ }^{9}$

Second, the rational approach or demonstrative method. This is a rational approach using the mind that specifically becomes a philosophical study with the widest. If we refer to the Qur'an, etymologically, the term ' $a q l$, reason, in its various forms is repeated 49

\footnotetext{
${ }^{7}$ Ibid., p. 135-136.

${ }^{8}$ Agus Purwanto, Ayat-Ayat Semesta (Bandung: Mizan, 2009), p. 28-29.

${ }^{9}$ Hassan Hanafi, Islam in the Modern World Vol II (Cairo: Dar Kebaa Bookshop, 2000), p. 377.
} 
times. ${ }^{10}$ Interestingly, all the words formed from 'aql, in the Qur'an are found in the form of verbs, such as ta'qilun, ya'qilun,' aqala, na'qilu, and ya'qilu. This means, God prioritizes the mind in His servants and more than that, the mind must always be used actively (because the verb indicates an activity) to be useful, not static.

Likewise, the Qur'anic commands relating to reason and thought, such as the terms yatafakkarun, tatafakkarun, and yatadabbarun, all of which are explicit teachings from God so that we always use our minds in all aspects of life. Associated with the understanding of reason in various forms, the Qur'an also uses the word science in various forms and their meanings 854 times, is the second most word after the word Allah. ${ }^{11}$ As we have understood, the optimal use of reason in thinking, analyzing, researching, and developing reason produces knowledge in its various forms, both natural sciences, social sciences, social sciences, humanity., as well as science related to religion (religious sciences). ${ }^{12}$

From some of the thematic evidence of the Qur'anic verse about reason and how it works broadly, it is clearly seen that the Qur'an strongly encourages Muslims to philosophize. From the perspective of the Qur'an, philosophizing here is nothing but a thought process in the broadest sense, not merely a product of thinking. Even philosophy also in the paradigm of the Qur'an is a kind of methodology of thinking towards all aspects of life: the universe, animals, human beings themselves, and God, the Creator.

Furthermore, in the perspective of Yusuf Qardhawi, the Qur'an uses the term ululalbab to show the potential and substance of reason to exist in human beings and to be utilized to the full. Ululalbab is what is defined as intellectuals, scholars, or intellectuals who are always praised by God. The term ulul or ulilalbab is repeated 16 times in the Qur'an. Uniquely, in one of the verses, the Qur'an describes ululalbab as intellectuals or intellectuals who wisely want to take the truth wherever it comes, by picking the best from the various sciences he listens to.

Let's look at one of the verses from the perspective of interpretive science: "Then deliver good news to my servants, those who like to listen to words, then follow which is

${ }^{10}$ Fuad Abdul Baqi, Al-Mu'jam Al-Mufahras li Alfazh Al-Quran (Kairo: Darul Hadith, 2007), p. 575. Ali Audah, Konkordansi Quran (Bandung: Mizan, 1997), p. 644-645; 742.

${ }^{11}$ Quraish Shihab, Membumikan Al-Qur'an (Bandung: Mizan, 1997), 62 dan 305.

12 Amin Abdullah, Islamic Studies di Perguruan Tinggi, (Yogyakarta: Pustaka Pelajar, 2006), p. 361-405. 
the best. They are the people who have been guided by God and they are the people who have reason" (Qur'an, 39: 17-18).

Although the term qawl, textually means words or sayings, but the meaning pointed to by the word is far broader than mere words / sayings. The term refers to all forms of concepts of thought, science, methodology, or discoveries that have been constructed by others but contain truth. At this point, a scholar (ululalbab) must be able to filter critically-objectively to take the best.

In Muhammad Asad's perspective, the verse interprets that the word gives a description of those who are willing to test every religious preposition (in the broadest sense) under the spotlight of their own mind, then take which of those prepositions is acceptable to reason, and discard which who can't stand the test of reason. Asad cites alRazi as saying that the verse is a complement to those who use rational argument (blasphemy al-aql), conduct critical discussions (nazhar), and make logical inferences (istidhal).

This, of course, is a rationalistic interpretation, in accordance with al-Razi's reputation. While Muhammad Ali as-Sabuni, in his book Shafwat al-Tafasir (the Core of the Tafsir), explains that the verse is intended as a compliment to those who like to listen to al-hadith (narration or description) and al-kalam (rational discussion) regarding ideas or views, then follow which one is the best. As-Sabuni quoted Ibn Abbas as saying that those who act in this way are able to recognize what is good and what is bad, or, in other words, critical spirits. ${ }^{13}$

Furthermore, the end of the verse says: ulaika al-ladzinahadahum Allah, waulaika hum ululalbab. Let's look at the praise of Allah at the end of the verse through the perspective of our commentator Quraish Shihab in his Tafsir Al-Mishbah. According to our commentator, the word of Allah ulaika al-ladzinahadahum Allah - they are - those whom Allah has indicated, suggest that it is the nature of Allah's guidance, and that guidance is to crave the truth and full readiness to follow it wherever it is found - that is hidayah Divine globally, and that is where all the detailed Divine guidance comes.

The word hum - they, after previously called the word ulaika - they, functioned to specialize the intended reference only to those spoken of in this verse. As if other than 298-299.

${ }^{13}$ Nurcholish Madjid, Islam Kemodernan dan Keindonesiaan, (Bandung: Mizan, 1999), p. 
those not discussed here - even though they also obtained guidance, the level and quality of the guidance they obtained cannot be compared with the guidance obtained by those discussed, to the extent that the others have not yet obtained His guidance. ${ }^{14}$

Through the paradigm of the Qur'an, with verses that explore about reason, thinking activities, and scholars (ululalbab), to find that there is no conflict between philosophy (which uses reasoning of the mind) with religion and a scholar (ululalbab) which in fact will be inclusive, open to science from wherever it comes. The merging of philosophy with religion and the inclusiveness paradigm of truth from wherever it comes again is exemplified very well by Muslim scientists and philosophers of the classical era from Al-Kindi, Al-Farabi, IbnRushd, Mulla Sadra, to Muhammad Iqbal.

The first philosopher, Al-Kindi, for example, departed from the premise of the principle that the main purpose of philosophy is to find the nature of everything and its essence of the initial truth, namely God, as well as the purpose of religion. Thus, there is no contradiction between religious truth and rational truth, because both are appearances of one truth. With this Aristotelian approach, Al-Kindi tried to convince philosophical truths to be achieved through pure reasoning.

Al-Kindi counters jurists and theologians who reject pre-Islamic ancient sciences (al-'ulum al-awail or Greek philosophy) with affirmative statements, "We should not be ashamed of acknowledging a virtue and taking it from wherever it comes," even if it comes from someone who is very different from us, because there is no priority in finding the truth except the truth itself ". In fact, he claims those who reject philosophy as "Those who are strangers to the truth and wear the crown of truth that they have no right to wear". ${ }^{15}$

A few decades later, Al-Farabi voiced that there is no contradiction between religion and philosophy because both express one truth. If philosophy expresses it directly, demonstratively, religion expresses it through imaginary symbols / intuition and reflection. Philosophers understand it with reason, that is through the burhani process which is only possible in this way it can be directly related to "active reason" (al-qaql al-fa' $a l$ ), whereas the Prophet accepts it directly from his own source, through his intuition. ${ }^{16}$

\footnotetext{
${ }^{14}$ Quraish Shihab, Tafsir Al-Mishbah, Vol.12 (Jakarta: Lentera Hati, 2002), p. 208.

${ }^{15}$ Jabiri, Formasi Nalar..., p. 396.

${ }^{16}$ Ibid., p. 408-409.
} 
About two centuries after Al-Farabi, Ibn Rushd appeared to want to repeat the philosophical project of Al-Kindi and Al-Farabi with richer and deeper discourses. Ibn Rushd emphatically requires people who are trained in thought to study philosophy and use demonstrative syllogism in searching for truths which he sees as the most perfect type of reasoning. He shouted openness in accessing philosophical knowledge even though it came from people of different religions. Illustration: a tool used to slaughter, then its validity as a means of slaughtering has nothing to do whether it is a tool of a religious person or not. However, IbnRushd retained an awareness of the universality and historicity of knowledge by saying: If the ancient sciences (Greek Philosophy) turned out to be in accordance with truth, then he would accept them happily while thanking them. If this is not in line with the truth, we must underline, remind the public about this while forgiving the authors. ${ }^{17}$

Once Ibn Rushd's masters presented philosophical concepts that did not conflict with religion, were even highly recommended and became an integral part of religion. Most of the philosophical discourses documented in his works impressed Europeans and appreciated them positively. Ibn Rushd's philosophical works were translated into European languages, analyzed, studied and applied well so as to inject some of the influences that led to European progress.

This contributive fact is recognized by scientists and the greatest historians of the world. Bertrand Russell, the great British philosopher who received the Nobel Prize in 1950, stated that the services of Ibn Rushd, could not be denied in opening up the dynamics of thinking of European Christians, and then from Europe spread throughout the World through science. Even Bertrand Russell asserted that had it not been for the Muslim philosopher, Christian Europe would not have moved from its original darkness, and would not have penetrated into the Renaissance, then into the Modern Age. ${ }^{18}$

Philip K. Hitti in his monumental work, History of the Arabs, also recognizes that IbnRushd when viewed by his influence on the Western world is the greatest Muslim philosopher. According to Hitti's findings, from the end of the 12th century to the end of the 16th century, Averroism (Ibn Rushd's thought discourse) remained the most dominant school of thought. With all its perfection, the intellectual movement pioneered by Ibn

${ }^{17}$ Abid Al-Jabiri, Filsafat Arab Islam, terj. Moch Nur Ichwan (Yogyakarta: Islamika, 2003), p. 181.

${ }^{18}$ Nurcholish Madjid, Kaki Langit Peradaban Islam, (Jakarta: Paramadina, 2009), p. 105. 
Rushd continued to be an important element in the development of European thought until the birth of modern experimental science. Seeing all these facts, Hitti came to the conclusion: There was no other (Muslim) writer who carved such a big influence. ${ }^{19}$

In the context of this third millennium too, an expert in Islamic philosophy, from Liverpool, John Moores University, Oliver Leaman, expressed honesty that Ibn Rushd must indeed be placed as the greatest thinker. ${ }^{20} \mathrm{With}$ this argument, it is no exaggeration if contemporary Moroccan philosopher Abid al-Jabiri is optimistic that in order to answer various problems today we must revive the spirit of Ibn Rushd (the Averrois spirit). AlJabiri invites Muslims to hold on to the most substantial part of the treasures of Averroism, namely the spirit of critical rationalism that produces new thoughts, not merely taking part in formality. ${ }^{21}$

Even Imam Al-Ghazali who was quite critical of philosophy continued to be inclusive of science until the end of his life. When recounting his intellectual wandering in search of truth in his inspiring autobiography, Al-Munqidz minadh dhalal, has voiced this principle of openness: "Even truth can be taken from a perverted expert, assuming that gold can be taken from the mud, because people those who have knowledge will not consider honey to be sweet, just because they get it in a burning vessel ". ${ }^{22}$

Third, the Intuitive method. This method uses a more heart / faith approach. Intuitive methods are commonly used to uncover supra-rational abstract phenomena, which are beyond the reach of our reason or are also called supernatural phenomena. Like God, Angels, Heaven-Hell, the meaning of life, transcendental experiences and others related to the spiritual realm. In the context of Islam, intuitive methods are applied very well in the world of Sufism / mysticism.

Intuitive methods in Sufism are carried out by performing tazkiyatunnafs (selfpurification) and riyadhah (if the soul) formulated by Sufi teachers with stages (maqomat) of the spiritual journey to God which usually begins with repentance and ends with mahabbah (love). Nevertheless, the intuitive method in Sufism is practiced by going through three stages namely takholli, tahalli, and tajalli. Takholli is the beginning of a

\footnotetext{
${ }^{19}$ Philip K. Hitti, History of The Arabs, (Jakarta: Serambi, 2010), p. 742.

${ }^{20}$ The Liang Gie, Pengantar Filsafat Ilmu (Yogyakarta: Liberty, 2007), p. xxi.

${ }^{21}$ M. Sirozi, dkk, Arah Baru Pendidikan Islam (Yogyakarta: Ar-Ruzz Media, 2006), p. 249-250

${ }^{22}$ Imam Al-Ghazali, Majmuaatur Rasail (Libanon: Beirut, 1996), p. 546.
} 
struggle such as a ritual in which a salik seeks to clean himself from all forms of disobedience, both outwardly immoral or immoral. After the process of takholli, just enter tahalli by decorating yourself with noble morals, such as sincerity, blessing, tawadhu, generous, qona'ah, tawakal, and others. Finally, when the process of takholli and tahalli is truly realized, only then with the permission of Allah a salik will experience tajalli, a spiritual enlightenment in which one witnesses the phenomenon of the unseen world with the sharpness of the bashirah, the eyes of his heart.

\section{Subordinative paradigms}

The third paradigm actually wants to remind firmly that the religious approach is more holistic in capturing reality, especially spiritual reality and the experience of human return to the Creator rather than the philosophical approach. Because religion, with an element of belief, an element of faith, not only understands but also experiences, whereas philosophy only seeks to understand not experience. If the philosophical approach is like seeing the reality of truth from a distance, not up close, then the religious approach actually sees the reality of truth up close while simultaneously touching and feeling it.

The greatest psychologist in the United States, William James in his masterpieces, The Varieties of Religious Experience, illustrates that religious experience goes beyond philosophical analysis. Even the power of religion, for James is not only beyond philosophy but also beyond morality. Morality might follow and obey the Creator. But morality may obey it with a heavy, frozen heart, and never stop feeling it as a burden. For religion in its manifestations which are strong and perfectly developed, service to the highest will never be considered as a burden. Tedious surrender was left far away, and was replaced by a mood of acceptance, which ranged from joyful peacefulness and enthusiastic happiness. ${ }^{23}$

Personal religion which is really lived with all my soul by each religious person, in James's view goes beyond philosophical studies. The attitude of a philosophical awareness, for example, considers surrender to the Creator and sacrifice as a necessity and lived at best without complaint. On the contrary, in religious life, self-enlightenment and selfsacrifice are supported by a positive attitude: Even unconditional surrender is often added to increase happiness. The period of tension in our souls is finished and replaced by the

${ }^{23}$ William James, The Varieties of Religious Experience, (Bandung: Mizan, 2004), p. 105. 
coming of peace that is full of happiness, deep breathing full of calm, and the present is eternal, without the need to worry about a conflicting future.

Thus, religion makes what is in other cases an obligation an easy and pleasant thing. If religion is the only intermediary that can produce results like this, the urgency of religion as a human faculty will not be denied. Religion will become an essential organ in our lives, carrying out functions that cannot be performed by other parts of our nature so well. $^{24}$

Both philosophy and morality are another part pointed out by James about his complete inability to aim at the nature of authentic religious experiences in addition to the religious experiences experienced by religious people themselves. For borrowing James's words: "Philosophy lives in words, but truth and fact well into our lives in ways that exceed verbal formulation". ${ }^{25}$ In the context of this meaning, religion is nothing but a kind of total reaction of a human child to life, man's total reaction upon life. ${ }^{26}$

In connection with this, James gives an example of the authentic religious attitude of religious people that will not be found in any philosophical discourse: God, You know what is best; make everything according to your will. Give what you want, as much as your will, whenever you want. Do me what you know to be the best, and all for your majesty. Put me wherever you wish, and do all your will for me in everything. When is there evil if you are near? I would rather be poor but be near You, than rich but far from You. I choose to be a pilgrim on earth with You, rather than having heaven but without You. Where there is Yourself is where heaven is; and if you are not in one place, that is death and hell. ${ }^{27}$ That is a unique love about the vital conversation between humans and the unseen God, vital conversation with the unseen divine, which would not exist in philosophical discourse.

This principle-fundamental difference is due to the philosophical approach to the reality it studies, let alone transcendental reality, always distant. While the religious approach, especially with its element of faith, when constructing reality, including transcendental reality is direct, there is no detention. Philosophical discourse when trying

\footnotetext{
${ }^{24}$ Ibid., p. $117-118$.

${ }^{25}$ Ibid., p. 356.

${ }^{26}$ Ibid., p. 45.

${ }^{27}$ Ibid., p. 109.
} 
to study supra-natural abstract objects, such as the existence of God, angels, heaven and hell, the subtle meanings of life, the meaning of suffering and sacrifice in life, for example, are often examined by philosophy, not facts / phenomena abstract supra-natural phenomena themselves, but doctrines, concepts, teachings, thoughts, or religious discourses that have been notified in the form of books, works, or even the Scriptures.

Not the direct existence of God, but discourses that talk about God that is struggled with philosophy; not the phenomena of angels, heaven and hell, and the meanings of life that are subtle, but the concepts that talk about angels, heaven and hell, and the meanings of life studied by philosophy. And so on, so that philosophy is distance in studying its objects. Distance is a concept, thought, teaching, or doctrines that have been recorded or documented. What is discussed is true silent facts that are no longer life, not the reality of truth that is really alive.

In contrast to philosophy, the religious approach, with its element of belief, towards religious reality is direct and not distant. Faith is an active quality, which reminds a person and connects that person in a dynamic relationship with the Creator, Creator and fellow human being. Faith is the ability to perceive the transcendent, and to reach it; hear the voice of God's call and welcome it with all my heart.

When approaching the transcendental reality of the existence of the God of heaven and hell, as well as the subtle meanings of life about human life, such as love, purpose in life, emptiness, suffering, and death, the faith approach seeks to be in direct contact with all transcendental realities and facts. that fact.

Initially, it may indeed be religious doctrines, discourses, and concepts of thought of scientists or scholars to be the entrance that approaches the reality of life. But after that, it is the active element of reality that plays a more intensive role with spiritual excitement not found in the philosophical approach. Not a discourse about God's existence, but a direct vision of God itself; Not the concepts of sacrifice in religion, but about the experience of making sacrifice itself; Not thoughts about man's devotion to his Lord, but direct contact with the roar of the devotion of every religious person to his Lord. 
In this context, said Wilfred Cantwell Smith: 'Faith is an engagement; it is the ability to see and respond, ${ }^{28}$ at the same time '. Engagement factor, this involvement in the religious approach necessitates the experience that distinguishes it from the philosophical approach which requires only knowledge. "There is a difference, writes Cantwell Smith, between knowing a teaching about salvation, on one hand, and experiencing being saved, on the other. There is a difference between knowing that Islam involves submitting one's will to God's will, as revealed in the Qur'an, and truly submitting personal will. There is a difference between having an accurate picture of a pattern of sacrifice and actually sacrificing what a high-value person sees, or experiencing himself as a sacrifice. ${ }^{29}$

\section{Conclusions: Integralistic Paradigm}

Reflecting on the explanation above, we can understand that in the perspective of Islam, philosophy or science in the broadest sense becomes part of our diversity. If we return to the core of our discussion, then we might be more inclined to the second paradigm, the integrative paradigm that unites science, philosophy and mysticism. The three regions are a unit that is highly recommended by Islam. For this reason, it is very appropriate that Yusuf Qardhawi said that knowledge for Muslims is religion, and religion for Muslims is science.

Science for us is religion, it is meant that our holy book and the Sunnah of our Prophet invites knowledge and considers it as worship and faridhah, both religious and worldly. Or be it science derived from revelation or science derived from the universe. God's revelation is God's command, and the universe is His creation. Thus, there is no contradiction between His creation and His commandments.

While the notion of religion for us is science, it is meant that our religion does not stand on the attitude of imitation and parrot our great ancestors or leaders. On the contrary, the Qur'an combats - in the most decisive way - that attitude, and invites all people to build their creed on evidence and conviction, not on prejudice and prejudice. ${ }^{30}$

Likewise in the view of Fazlur Rahman. According to Rahman, from an Islamic point of view, science is already contained essentially in the Qur'an. Religion means

\footnotetext{
${ }^{28}$ Wilfred Cantwell Smith, Faith and Belief: The Difference Between Them, (Oxford: Oneworld Publication, 1998), p. 168.

${ }^{29}$ Wilfred Cantwell Smith, Memburu Makna Agama, (Bandung: Mizan, 2004), p. 228.

${ }^{30}$ Yusuf Qardhawi, Al-Qur'an Berbicara Tentang Akal dan Ilmu Pengetahuan, (Jakarta: Gema Insani, 1998), p. 117.
} 
knowledge, and knowledge means religion. Therefore, there is no dichotomy between religion and science. That is, in the ideal level of the Qur'anic paradigm, every person who is religious should have knowledge and everyone who has knowledge, who has used his intellectual faculties to become people of knowledge, must be religious. ${ }^{31}$

In the historical landscape of classical Islamic civilization, we have witnessed that religion and philosophy, religion and science, faith and philosophy, and faith and science are organic unity that are inseparable from one another. In the touch of Muslim philosophers, between faith and philosophy incarnates an integrated, integral, and indeed organic relationship that cannot be separated from one another.

At this point, we must hear the appeal of contemporary Muslim scholars that we must dare to take science, science and philosophy back from the hands of Westerners and Europeans as our lost property. Both science, science and philosophy are part of the religion and diversity of all of us. Finally to see the urgency of philosophical studies for Muslims both today and in the future, let me close the discourse of this chapter with the appeal of the great Muslim scientist of Pakistan, Fazlur Rahman:

"Philosophy is however a perennial intellectual need and has to be allowed to flourish both for its own sake and for the sake of other disciplines, since it inculcates a much-needed analytical-critical spirit and generates new ideas that become important intellectual tools for other sciences not least for religion and theology. Therefore a people that deprives itself of philosophy necessarily expose itself to starvation in terms of fresh ideas-in fact it commits intellectual suicide". ${ }^{32}$

\footnotetext{
${ }^{31}$ Sutrisno, Fazlur Rahman..., p. 208.

${ }^{32}$ Fazlur Rahman, Islam and Modernity (Chicago: The University of Chicago Press, 1982), p. 157-158.
} 


\section{DAFTAR PUSTAKA}

Abdullah, Amin. Islamic Studies di Perguruan Tinggi. Yogyakarta: Pustaka Pelajar, 2006.

Abid al-Jabiri, Formasi Nalar Arab. Terj. Imam Khoiri. Yogyakarta: Ircisod, 2003.

Abid Al-Jabiri. Filsafat Arab Islam. Terj. Moch Nur Ichwan. Yogyakarta: Islamika, 2003.

Al-Ghazali, Imam. Majmuaatur Rasail. Libanon: Beirut, 1996.

Armstrong, Karen. The Case for God. London: The Bodley Head, 2009. Dawkins, Richard. The God Delusion. London: Black Swan, 2007.

Audah, Ali. Konkordansi Quran. Bandung: Mizan, 1997.

Baqi, Fuad Abdul. Al-Mu'jam Al-Mufahras li Alfazh Al-Quran. Kairo: Darul Hadith, 2007.

Gie, The Liang. Pengantar Filsafat Ilmu. Yogyakarta: Liberty, 2007.

Hanafi, Hassan. Islam in the Modern World Vol II. Cairo: Dar Kebaa Bookshop, 2000.

Hanafi. Pengantar Teologi Islam. Jakarta: Pustaka Al-Husna, 2003.

Hitti, Philip K. History of The Arabs. Jakarta: Serambi, 2010.

Juhaya S. Praja, Aliran-aliran Filsafat dan Etika. Bogor: Kencana, 2003

Kartanegara, Mulyadhi. Integrasi Ilmu. Bandung: Arasy, 2005.

Leahy, Louis. Aliran-Aliran Besar Ateisme. Yogyakarta: Kanisius, 1985.

Madjid, Nurcholish. Islam Kemodernan dan Keindonesiaan. Bandung: Mizan, 1999. . Kaki Langit Peradaban Islam. Jakarta: Paramadina, 2009.

Purwanto, Agus. Ayat-Ayat Semesta. Bandung: Mizan, 2009.

Qardhawi, Yusuf. Al-Qur'an Berbicara Tentang Akal dan Ilmu Pengetahuan. Jakarta: Gema Insani, 1998.

Rahman, Fazlur. Islam and Modernity. Chicago: The University of Chicago Press, 1982.

Raines, John (eds.). Marx Tentang Agama. Terj. Ilham B. Saenong. Jakarta: Teraju.

Russell, Bertran. Bertuhan Tanpa Agama. Yogyakarta: Resist Book, 2008. 
Sirozi dkk. Arah Baru Pendidikan Islam. Yogyakarta: Ar-Ruzz Media, 2006.

Sutrisno. Fazlur Rahman. Yogyakarta: Pustaka Pelajar, 2011.

Smith, Wilfred Cantwell. Faith and Belief: The Difference Between Them. Oxford: Oneworld Publication, 1998. . Memburu Makna Agama. Bandung: Mizan, 2004.

Shihab, Quraish. Membumikan Al-Qur'an. Bandung: Mizan, 1997. . Tafsir Al-Mishbah, Vol.12. Jakarta: Lentera Hati, 2002.

William J. Wainwright, Philosophy of Religion (New York: Wadsworth Publishing Company, 1999).

William James, The Varieties of Religious Experience. Bandung: Mizan, 2004. 